\title{
AKIBAT HUKUM PERJANJIAN JUAL BELI HAK ATAS TANAH
}

\author{
Made Erik Krismeina Legawantara, Desak Gde Dwi Arini, Luh Putu Suryani \\ Fakultas Hukum Universitas Warmadewa, Denpasar - Bali, Indonesia
}

\begin{abstract}
Abstrak
Jual beli biasanya dilakukan dengan perjanjian atau yang dikenal dengan perjanjian jual beli, berdasarkan hukum adat perjanjian jual beli merupakan perjanjian yang bersifat riil, maksudnya penyerahan barang yang diperjanjikan merupakan syarat yang mutlak dipenuhi untuk adanya sebuah perjanjian. Penelitian in bertujuan untuk mengetahui tentang pengaturan perjanjian jual beli hak atas tanah dan mengetahui akibat hukum perjanjian jual beli hak atas tanah apabila terjadi wanprestasi. Metode yang digunakan dalam penelitian yaitu metode hukum normative dengan pendekatan perundang-undangan (satute aproach) dan pendekatan konseptual. Jenis data yang digunakan ada dua yaitu Primer (UU dan Perundang-Undangan) sebagai data utama dan data sekunder (sumber kepustakaan, buku-buku dan jurnal penelitian). Data yang dianalisis disajikan dalam bentuk deskripsi. Hasil Penelitian menunjukan bahwa engaturan jual beli hak atas tanah diatur dalam pasal 1457 . KUH Perdata yang menentukan bahwa jual beli adalah kesepakatan antara pihak pembeli dan pihak penjual dalam suatu perjanjian dimana syarat sahnya perjanjian wajib memenuhi syarat subyektif dan syarat obyektif, dengan konsekwensi bahwa perjanjian tidak bisa dibatalkan secara sepihak karena wajib dilaksanakan dengan etikad baik. Kemudian, akibat Hukum Wanprestasi bagi Para Pihak Dalam Pembatalan Akta Perjanjian Pengikatan Jual Beli Hak Atas Tanah diatur dalam Pasal 1366 KUH Perdata yang menentukan bahwa setiap orang bertanggung jawab tidak saja untuk kerugian yang disebabkan perbuatannya, tetapi juga untuk kerugian yang disebabkan oleh kelalaian atau kekurang hati-hatian. Pasal 1366 KUH Perdata menjelaskan mengenai tanggung jawab seseorang yang telah melakukan kerugian kepada orang lain/pihak lain, baik itu karena perbuatannya sendiri atau pun karena kelalaian dan kekurang hati-hatian yang mengakibatkan pihak lain menderita kerugian olehnya.
\end{abstract}

Kata kunci: Hak Atas Tanah; Jual Beli; Perjanjian

\begin{abstract}
Sale and purchase is usually done by an agreement or what is known as a sale and purchase agreement, based on customary law a sale and purchase agreement is a real agreement, meaning that the delivery of the goods agreed upon is an absolute requirement fulfilled for the existence of an agreement. This research aims to find out about the arrangement of the land purchase agreement and find out the legal consequences of the land purchase agreement if there is a default. The method used in this research is the normative legal method with the statutory approach (satute aproach) and the conceptual approach. There are two types of data used, namely Primary (Laws and Regulations) as primary data and secondary data (sources of literature, books and research journals). Data analyzed are presented in the form of descriptions. Research results show that the sale and purchase rights of land rights are regulated in article 1457. The Civil Code which determines that buying and selling is an agreement between the buyer and the seller in an agreement where the legal terms of the agreement must meet subjective and objective conditions, with the consequence that the agreement is not can be canceled unilaterally because it must be implemented in good faith. Then, due to the Default Law for the Parties In Canceling the Deed of Agreement on the Sale and Purchase of Land Rights, it is regulated in Article 1366 of the Civil Code which stipulates that everyone is responsible not only for losses caused by his actions, but also for losses caused by negligence or indifference careful. Article 1366 of the Civil Code explains the responsibility of someone who has done harm to another person / other party, either because of his own actions or due to negligence and carelessness that causes other parties to suffer losses from him.
\end{abstract}

Keywords: Land Right; Sale and purchase; Agreement

\section{PENDAHULUAN}

Dalam mewujudkan pembangunan nasional yang adil dan makmur berdasarkan Pancasila dan Undang-Undang Dasar Negara Republik Indonesia tahun 1945 yang berdaulat, aman, tentram, tertib dalam lingkungan pergaulan dunia, untuk merealisasikan tujuan tersebut dibutuhkan dana yang cukup 
besar sehingga pemerintah daerah terus menggali dana dari berbagai sektor salah satu diantaranya berasal dari sektor pajak. Seiring dengan pelaksanaan otonomi daerah, pemerintah daerah harus cerdas mengelola kinerja keuangannya.

Salah satu jenis pajak yang diterapkan yaitu pajak dalam transaksi jual beli tanah. Perkembangannya pajak ini tentu menjadi perhatian utama dengan melihat fenomena tumbuhnya aktivitas mengenai kepemilikan maupun peralihan kepemilikan lahan pertanahan yang diakibatkan pesatnya laju kepadatan penduduk Indonesia. Hal ini dapat dilihat dari jumlah penduduk yang terus meningkat dengan lahan yang tetap sehingga menyebabkan selisih perbandingan yang semakin besar antara jumlah penduduk dan luas lahan. Pajak dalam transaksi jual-beli tanah terbagi atas; Pajak Penjual dan pajak pembeli. Pajak penjual, dikenakan Pajak Penghasilan (PPh). Dasar hukum pengenaan PPh terbaru untuk penjual tanah adalah Pasal 1 ayat (1) Peraturan Pemerintah (PP) Republik Indonesia Nomor 34 Tahun 2016 Tentang Pajak Penghasilan atas Penghasilan dari Pengalihan Hak atas Tanah dan/atau Bangunan, dan Perjanjian Pengikatan Jual Beli atas Tanah dan/atau Bangunan beserta Perubahannya:

"Atas penghasilan yang diterima atau diperoleh orang pribadi atau badan dari:

1. Pengalihan hak atas tanah dan/atau bangunan; atau

2. Perjanjian pengikatan jual beli atas tanah dan/atau bangunan beserta perubahannya, terutang Pajak Penghasilan yang bersifat final".

Dalam masyarakat jual beli bukanlah hal yang baru, karena jual beli telah dilakukan sejak zaman dahulu. Jual beli biasanya dilakukan dengan perjanjian atau yang dikenal dengan perjanjian jual beli, berdasarkan hukum adat perjanjian jual beli merupakan perjanjian yang bersifat riil, maksudnya penyerahan barang yang diperjanjikan merupakan syarat yang mutlak dipenuhi untuk adanya sebuah perjanjian. Dengan kata lain, apabila telah diperjanjikan sesuatu hal akan tetapi dalam prakteknya belum diserahkan objek perjanjian tersebut maka perjanjian tersebut dianggap tidak ada atau belum ada perjanjian (Subekti, 1988). Selain itu juga menganut asas terang dan tunai, yaitu jual beli berupa penyerahan hak untuk selama-lamanya dan pada saat itu juga dilakukan pembayarannya oleh pembeli yang diterima oleh penjual (Harsono, 2008). Keadaan tersebut berbeda dengan ketentuan tentang perjanjian jual beli yang diatur dalam Kitab Undang-Undang Hukum Perdata, karena sesuai dengan Pasal 1458 Kitab Undang-Undang Hukum Perdata (KUH Perdata) menentukan bahwa "jual beli dianggap telah terjadi antara kedua belah pihak sewaktu mereka telah mencapai sepakat tentang barang dan harga, meskipun barang itu belum diserahkan maupun harganya belum dibayar".

Atas dasar pasal tersebut, terlihat bahwa perjanjian dianggap telah ada sejak tercapai kata sepakat, meskipun barang yang diperjanjikan belum diserahkan maupun harganya belum dibayar. Jual beli dalam masyarakat dengan objek jual beli hak atas tanah, juga dilakukan dengan perjanjian untuk lebih memberikan kepastian hukum, karena hak atas tanah termasuk objek perjanjian yang secara khusus diatur dalam peraturan perundang-undangan yang berlaku di mana setiap perbuatan hukum yang menyangkut tentang hak atas tanah terikat atau harus mengikuti ketentuan yang diatur dalam peraturan perundangundangan tersebut. Maksudnya pihak yang akan melakukan perbuatan hukum yang menyangkut tentang hak atas tanah, harus tunduk terhadap aturan hukum yang mengatur atau berkaitan dengan pengaturan tentang hak atas tanah atau dengan kata lain pihak yang melakukan perbuatan melakukannya, akan tetapi dia terikat dengan ketentuan hukum yang mengatur tentang Hak Atas Tanah (HAT).

Beberapa penelitian yang diluncurkan oleh para peneliti sebelumnya telah mengkaji tentang transaksi jual beli seperti Fajaruddin, (2017); Hayati (2016); Luthfi \& Khisni (2018); Misbach, Ryandono, \& Prasetyo (2019); Rosandi (2016) mengatakan bahwa erlindungan hukum terhadap pembeli hak atas tanah karena jual beli terhadap tanah yang belum didaftarkan apabila yang memperolehnya dengan itikad baik tetap mendapatkan perlindungan berupa perlindungan hukum represif. Kemudian, (Santyaningtyas \& Zubaidi, 2020) menyatakan bahwa Komite Ajudikasi sebagai pelaksana PTSL harus berkoordinasi dengan PPAT untuk memastikan bahwa PTSL memenuhi tahap penelitian data hukum sehingga pendaftaran tanah yang teratur dan lengkap tercapai dan memberikan kepastian hukum kepemilikan hak atas tanah.

Sehubungan dengan hal tersebut diatas, perjanjian jual beli tidak pernah diatur dalam peraturan perundang-undangan yang berkaitan dengan hak atas tanah, sehingga kedudukan serta bagaimana kekuatan hukum perjanjian jual beli terkadang masih dipertanyakan terhadap pelaksanaan jual beli hak atas tanah. Dalam pelaksanaanya, perjanjian tersebut senantiasa tidak berjalan sesuai dengan 
kesepakatan yang diinginkan oleh para pihak. Dalam kondisi tertentu dapat timbul masalah yang mengakibatkan terjadinya ingkar janji atau wanprestasi. Beberapa diantaranya bentuk ingkar janji yang terjadi dalam pelaksaan perjanjian pengikatan jual beli mengenai keterlambatan pembayaran dari pihak pembeli, pihak penjual yang menjual objek jual beli kepada pihak lain, pihak penjual yang tidak melakukan kewajibannya seperti tidak menyerahkan bukti tanda milik tanah tersebut juga sertifikat kepada pihak pembeli, tidak menyerahkan objek jual beli kepada pembeli, dan menjadikan objek jual beli sebagai jaminan di bank, menjual ataupun menyewakan kepada orang lain. Berdasarkan latar belakang, maka penelitian ini bertujuan untuk mengetahui tentang pengaturan perjanjian jual beli hak atas tanah dan mengetahui akibat hukum perjanjian jual beli hak atas tanah apabila terjadi wanprestasi.

\section{METODE PENELITIAN}

Penelitian ini didesain dengan menggunakan metode hukum normative dan pendekatan perundangundangan (satute aproach) dan pendekatan konseptual (Muhammad, 2004). Pendekatan perundangundangan dilakukan untuk meneliti akibat hukum perjanjian jual beli hak atas tanah. Ada dua jenis sumber data dalam penelitian ini yaitu data primer yang berasal dari:

1. Undang-Undang Dasar RI Tahun 1945

2. Kitab Undang-Undang Hukum Perdata (KUH Perdata)

3. Undang-Undang Nomor 36 Tahun 2008 Tentang Perubahan Keempat Atas Undang-Undang nomor 7 Tahun 1983 Tentang Pajak Penghasilan

4. Peraturan Pemerintah (PP) Republik Indonesia Nomor 34 Tahun 2016 Tentang Pajak Penghasilan atas Penghasilan dari Pengalihan Hak atas Tanah.

Kemudian, bahan sekunder yaitu bahan hukum yang bersumber dari rancangan peraturan perundangundangan, hasil ilmiah sarjana, hasil-hasil penelitian, jurnal-jurnal hukum, disertai tulisan-tulisan para ahli di bidang hukum nasional maupun internasional yang didapat dari studi kepustakaan yang terkait dengan pemasalahan. Setelah bahan-bahan hukum tersebut dikumpulkan, selanjutnya bahan hukum tersebut dianalisis secara deskriptif analisis yang kemudian disajikan dalam bentuk deskriptif. Maksud dari deskriptif ialah bahwa penyajian dengan menggambarkan secara lengkap tentang aspek-aspek tertentu yang berkaitan dengan masalah penulisan ini dengan tambahan diberikan argumentasi hukum.

\section{HASIL PENELITIAN DAN PEMBAHASAN Pengaturan Perjanjian Jual Beli Hak atas Tanah}

Terang dan tunai dijadikan dasar dalam bertransaksi pertanahan. Terang dalam artian adanya keterbukaan, kejelasan 0bjek dan subjek pemilik beserta kelengkapan surat-surat pembuktian pemilik tanah. Tunai artinya pembayaran yang seketika dan sekaligus (Muhamad, 2002). Faktanya, dengan alasan yang beragam konsep tersebut sering tidak terpenuhi tetapi bukan berarti transaksi tidak dapat dilaksanakan karena terdapat instrumen lain berupa akta pengikatan jual beli menjadi daya ikat dan transaksi dinyatakan sudah terjadi sambil menunggu surat yang belum selsai, syarat belum dipenuhi karena proses pembayaran yang belum lunas. Terdapat dua versi akta jual beli:

1. Pernjanjian jual beli yang mengikat adalah janji karena biasanya harga tidak dibayar penuh (biasanya disebut sebagai jual beli mengikat tidak dibayar penuh).

2. Mengikat akta jual beli, pembayaran dibayar penuh, tetapi akta pembelian tidak dapat dieksekusi sebelum PPAT yang berwewenang karena masih ada proses yang belum selesai, misalnya: masih dalam proses split sertifikat masih menggabungkan serta alasan lainnya menyebabkan akta jual beli tidak dapat dibuat (biasanya disebut pengikat jual belum lunas (Bintang \& Dahlan, 2002:23)

Jika formulir mengikat untuk penjualan dan pembelian tidak diatur maka tidak ada surat kuasa kecuali persyaratan untuk memenuhio kewajiban. Sementara, jika pembayaran dilunasi dan pengikat jual beli dibayar bersamaan, hal ini disertai dengan otorisasi penjualan dari penjual dan pembeli. Jadi ketika semua persyaratan telah dipenuhi tanpa kehadiran penjual yang diminta karena mereka sudah diwakili dengan surat kuasa, dengan penerbit suara kuasa menjual ke pembeli, notaris /PPAT dapat segera menandatangani akta penjualan untuk nanti memproses nama sertifikat. Kekuatan untuk menjual milik kategori kekuatan yang dugunakan untuk mentranfer tangan suatu barang yang hanya dapat dilakukan oelh pemiliknya. Itulah sebabnya surat kuasa demgan kata-kata yang jelas dinyatakn dalam dokumen untuk surat kuasa ini (pasal 1796 KUHPerdata). 
Kewenangan untuk menjual ini dapat diperkenalkan sebagai klausul dalam penjualan dan pembelian yang mengikat. Selain itu, juga dapat berdiri sendiri dalam bentuk akta terpisah. Jadi, ketika menandatangani maka anda menandatangani dua tindakan: perjanjian pembelian yang mengikat dan surat kuasa untuk menjual. Dalam hal surat kuasa untuk menjual akses sebagai klausul dalam perjanjian pembelian yang mengikat hanya kata penrjanjian pembelian yang mengikat (PJB) yang ditandatangani.

Dalam satu kasus, kekuatan penjual tampaknya dimasukan sebagai klausul dalam perjanjian pembelain yang mengikat. Sebelum menandatangani perjanjian pembelian yang mengikat, notaris membca konten akta yang akan menandatangani dan pembeli menjelaskan ini sebagai tanda, disepakati bersama dan disepakati.

Jika klausul menyatakan/mengatur dengan kata-kata ketat yang memberikan kekuatan pembelian untuk menjual, maka pada saat kepatuhan dengan semua persyaratan untuk meningkatkan ikatan penjualan dengan kata jual beli sebegai penjual. Pembeli bertindak sebgai surat kuasa untuk penjual berdasarkan surat kuasa yang sudah ada dalam perjanjian penjualan dan pembelian yang mengikat dimana penjualan dan pembelian ditanda tangani dengan sempurna oleh penjual dan pembeli. Namun, jika perjanjian pembelian yang mengikat tidak memiliki otorisasi penjual sperti yang dijelaskan sebelumnya, ia dapat melapor kepada pihak berwenang.

Untuk jenis perjanjian jual beli yang mengikat, surat kuasa dalam perjanjian jual beli yang mengikat adalah mutlak yang berarti tidak dapat dicabut dan tidak akan kedaluwarsa karena alasan yang ditentukan dalam pasal 1813 KUH Perdata. Ini untuk memastikan kepastian hukum bagi pembeli yang telah membayar harga penuh tetapi tidak dieksekusi setelah nama. Perlu diketahui bahwa jika surat kuasa ini merupakan bagian yang tidak terpisahkan dari perjanjian jual beli yang mengikat, dalam hal akta perjanjian jual beli yang mengikat, ditandatangani dengan sempurna tanpa ada elemen kesalahan, paksaan atau penipuan. Proses penjualan dan pembelian yang mengikat tetap menjadi perjanjian jual beli dan nama sertifikat memang telah berakhir sebgaiman mestinya, kecuali jika proxy digunakan semata-mata menjaula asset tanpa dikaitkan dengan perjanjian pembelian surat kuasa murni dapat ditarik dengan menggunakan akta penarikan kekuasaan dalam hal jual beli dan pemindahan nama tidak terjadi. Namun, jika nama dibalik akta pembelian dan pembelia telah terjadi. Pembatalan penjualan dan pembelian harus dilakukan melalui gugatan ke pengadilan yang kompeten jika dapat membuktikan bahwa kuasa diberikan oleh karena kesalahan, paksaan ataun penipuan.

Perjanjian jual beli tanah disimpulkan untuk membuat komitmen smentara sebelum akta resmi jual beli dilakukan dihadapan Petuga Pembuatan Akta Tanah (PPAT). Secara umum, isi perjanjian untuk mengikat penjualan dan pembelian tanah adalah perjanjian penjual untuk berkomitmen untuk menjual kepada pembeli, disertai dengan memberikan tanda atau uang muka berdasarkan perjanjjian. Pada dasarnya, pengikat pekerja perjanjian pembelian tanah dirusak untuk alasan tertentu seperti pembayaran harga tidak dibayar. Pengikat perjanjian pembelian berisi perjanjian sperti jumlah harga pada saat pembayaran dan perjanjian pembelian (Mashudi \& Ali, 2001).

\section{Akibat Hukum Perjanjian Jual Beli Hak atas Tanah apabila Terjadi Wanprestasi}

Suatu perjanjian jual beli dapat berjalan dan terlaksana dengan baik apabila para pihak telah memenuhi isi perjanjian jual beli mengenai janji-janji dan kewajiban para pihak seperti yang telah dituangkan dalam perjanjian tanpa ada salah satu pihak yang dirugikan dalam perjanjian jual beli. Tetapi adakalanya perjnjian jual beli hak atas tanh tidak terlaksana dengan baik apabila salah satu pihak tidak memenuhi apa yang telah dijanjikan dalam perjanjian jual beli yang dibuat berdasarkan kesepatakan bersama pihak yang tidak melakukan kewajiban- kewajibannya sesuai dengan apa yang telah diperjanjikannya maka dapat dikatakan melakukan wanprestasi. Seseorang melakukan perbuatan wanprestasi dalam suatu perjanjian jual beli terkadang tidaklah mudah karena sering sekali dalam suatu perjanjian tidak diisikan secara jelas dan tepat kapan suatu pihak diwajibkan untuk melakukan kewajiban-kewajibannya atau janji-janjinya seperti apa yang diperjanjikan dalam perjanjian jual beli hak atas tanah yang para pihak lakukan.

Menurut Subekti (1988) dari pengertian dan penjelasannya di internet dengan website www.wanprestasi Indonesia-online.co.id wanprestasi memiliki arti prestasi buruk artinya suatu keadaan yang dikarenakan kelalaian atau kesalahan salah satu pihak karena salah satu pihak melanggar/tidak dapat memenuhi kewajiban-kewajibannya seperti apa yang telah disepakati dan apa 
saja yang telah diperjanjikan dalam kontak yang dibuat oleh para pihak dan tentunya, kesepakatan yang mereka lakukan bukan dalam keadaan memaksa namun memang berdasarkan atas persetujuan kedua belah pihak. www.wanpretasi Indonesia-online.co.id, diakses tanggal 3 Januari 2020 pada pukul 22.00 .

Wanprestasi berbeda dari tindakan melawan hukum meskipun banyak orang umumnya menganggap bahwa default adalah bagian dari tindakan melawan hukum karena seorang debitur yang gagal membayar hutang tepat waktu jelas merupakan pelanggaran terhadap hak-hak debitu dan kreditur. Anggapan semacam itu benar adanya, tetapi ketika akan dituangkan dalam bentuk kasus tertulis, hal itu tentu saja tidak boleh dikaitkan antara nilai-nilai standar dan tindakan melawan hukum karena akan menyebabkan kesalahan yang pada akhirnya akan mengarah pada luput dari tujuan persidangan itu sendiri.

Biasanya untuk dapat mengatakan pihak pembeli telah melakukan wanprestasi atau tidak melakukan wanprestasi tergantung dari perjanjian yang para pihak lakukan. Dalam wanprestasi biasanya perjanjian terlebih dahulu dilakukan/dibuat karena dari perjanjian jual beli inilah yang nantinya akan dapat menimbulkan wanprestasi. Tentunya dalam membuat suatu perjanjian antara kedua belah pihak harus selalu berpedoman pada Pasal 1320 KUH Perdata, mengenai syarat sahnya suatu perjanjian jual beli adapun keempat syarat yang harus dipenuhi, yaitu kesepakatan para pihak untuk mengikatkan dirinya, kecakapan para pihak untuk bertindak/membuat suatu perjanjian jual beli, suatu pokok persoalan tertentu, suatu sebab yang tidak terlarang. Dari keempat persyaratan untuk melakukan perjanjian yang sah inilah, bila dilanggar oleh pihak pembeli dapat menimbulkan terjadinya wanprestasi dan kerugian yang dialami pihak penjual dalam suatu perjanjian jual beli yang dibuat oleh para pihak berdasarkan kesepakatan bersama. Bila pihak pembeli melakukan wanprestasi dan mengakibatkan kerugian kepada pihak penjual karena kelalaian dari pihak pembeli, maka seperti yang tertuang dalam pasal 1366 KUH Perdata yang menentukan bahwa setiap orang bertanggung jawab tidak saja untuk kerugian yang disebabkan perbuatannya, tetapi juga untuk kerugian yang disebabkan oleh kelalaian atau kekurang hati-hatian.

Dalam perjanjian jual beli hak atas tanah antara pihak penjual dengan pihak pembeli berdasarkan kesepakatan bersama, wanprestasi yang dilakukan tidaklah jauh berbeda dengan wanprestasi terhadap bentuk-bentuk perjanjian lainnya karena wanprestasi dapat timbul dikarenakan akibat dari sebuah perjanjian. Dimana wanprestasi yang dimaksud adalah seseorang yang telah lalai dalam memenuhi sebagaimana kewajiban-kewajibannya dalam perjanjian yang mereka lakukan. Dalam hal ini yang dimaksud adalah baik lalai dalam memenuhi sebagian kewajiban, lalai memenuhi seluruh kewajibannya/tidak melakukan kewajibannya sama sekali, lalai dalam memenuhi apa yang diperjanjikannya, lalai dalam melakukan sesuatu yang menurut perjanjian tidak boleh dan tidak dapat dilakukan.

Ada dua kewajiban dasar, yaitu pengiriman barang dan jaminan bahwa pelanggan dapat memiliki barang dengan tenang, sementara pelanggan wajib membayar harga pada waktu dan tempat yang ditentukan. Pihak ketiga atau bank juga memiliki hak dan kewajiban, antara lain pihak ketiga atau bank berkewajiban untuk membayar jumlah yang telah disepakati pelanggan untuk dibayarkan kepada penjual dan untuk menjamin bahwa pengiriman dana ini benar-benar aman dan menjangkau mereka yang memiliki hak harus menerimanya. Selain itu, pihak ketiga atau bank juga memiliki hak untuk mengganti biaya administrasi untuk memproses pembayaran untuk hak-hak dasar dalam perjanjian pembelian dan pembelian.

\section{SIMPULAN}

Pengaturan jual beli hak atas tanah diatur dalam pasal 1457. KUH Perdata yang menentukan bahwa jual beli adalah kesepakatan antara pihak pembeli dan pihak penjual dalam suatu perjanjian dimana syarat sahnya perjanjian wajib memenuhi syarat subyektif dan syarat obyektif, dengan konsekwensi bahwa perjanjian tidak bisa dibatalkan secara sepihak karena wajib dilaksanakan dengan etikad baik. Kemudian, akibat Hukum Wanprestasi bagi Para Pihak Dalam Pembatalan Akta Perjanjian Pengikatan Jual Beli Hak Atas Tanah diatur dalam Pasal 1366 KUH Perdata yang menentukan bahwa setiap orang bertanggung jawab tidak saja untuk kerugian yang disebabkan perbuatannya, tetapi juga untuk kerugian yang disebabkan oleh kelalaian atau kekurang hati-hatian. Pasal 1366 KUH Perdata menjelaskan mengenai tanggung jawab seseorang yang telah melakukan kerugian kepada orang 
lain/pihak lain, baik itu karena perbuatannya sendiri atau pun karena kelalaian dan kekurang hatihatian yang mengakibatkan pihak lain menderita kerugian olehnya.

Ketika terjadi wanprestasi dalam suatu perjanjian jual beli, namun tidak semua perjanjian jual beli terdapat wanprestasi tetapi ada saja beberapa perjanjian jual beli yang bermasalah atau terjadi wanprestasi. Biasanya wanprestasi ini terjadi dikarenakan adanya salah satu pihak yang tidak memenuhi kewajiban-kewajiban terutama dalam hal batas waktu pembayaran. Jika para pihak melakukan transaksi jual beli, maka terlebih para pihak harus melakukan pengikatan jual beli. Melalui penelitian ini diharapkan kepada Notaris agar lebih berhati-hati di dalam menandatangani akta autentik dalam jual beli tanah untuk mencegah terjadinya kasus wanprestasi. Kemudian, kepada para pihak, dalam membuat suatu perjanjian jual beli tanah wajib dilakukan dengan etikad baik, agar transaksi bisnis berjalan dengan lancar.

\section{DAFTAR PUSTAKA}

Bintang, S., \& Dahlan. (2002). Pokok-Pokok Hukum Bisnis dan Hukum Ekonomi. Bandung: Citra Aditya Bhakti.

Fajaruddin. (2017). Pembatalan Perjanjian Jual Beli Hak atas Tanah Akibat Adanya Unsur Khilaf. De Lega Lata, 2(2), 285-306.

Harsono, B. (2008). Hukum Agraria Indonesia, Perauran Pelaksanaan Republik Indonesia. Jakarta: Djambatan.

Hayati, N. (2016). Peralihan Hak Dalam Jual Beli Hak Atas Tanah (Suatu Tinjauan terhadap Perjanjian Jual Beli dalam Konsep Hukum Barat dan Hukum Adat dalam Kerangka Hukum Tanah Nasional). Lex Jurnalica, 13(3), 278-289.

Luthfi, M. A., \& Khisni, A. (2018). Akibat Hukum Terhadap Peralihan Hak Milik Atas Tanah Yang Belum Lunas Pembayarannya. Jurnal Akta, 5(1), 65-74.

Mashudi, H., \& Ali, M. C. (2001). Pengertian-Pengertian Elementer Hukum Perjanjian Perdata (Ceatakan I). Bandung: Mandar Maju.

Misbach, M. N., Ryandono, M. N. H., \& Prasetyo, A. (2019). An Overview of Islamic Law Against Buying and Selling Sand-Land With A Liberation System (Case Study in Mount Wurung of Mojokerto Regency). Airlangga International Journal of Islamic Economics and Finance, 1(1), 6-19.

Muhamad, A. (2002). Hukum Perikatan. Bandung: Alumni.

Muhammad, A. (2004). Hukum dan Penelitian Hukum. Bandung: PT. Citra Aditya Bakti.

Rosandi, B. H. P. (2016). Akibat Hukum Jual Beli Hak Atas Tanah Yang Belum Didaftarkan. Jurnal IUS, IV(3), 424-435.

Santyaningtyas, A. C., \& Zubaidi, R. (2020). Role of Land Deed Officials In Legal Satisfaction Guarantee For Complete Systematic Land Registration. Jurnal Notariil, 5(1), 49-57.

Subekti, R. (1988). Aspek-aspek Hukum Perikatan Nasional. Bandung: PT. Citra Aditya Bakti. www.wanprestasi Indonesia Online.co.id, diakses tanggal 03 Januari 2020. Pukul 22.00. 